\title{
RITUALIDADES DO MISTÉRIO PESSOAL: O SEGREDO DE ORIXÁ NO BATUQUE AFRO-SUL
}

\author{
Marcus Vinicius de Souza Nunes ${ }^{1}$ \\ DOI 10.26512/revistacalundu.v4i2.31960
}

\section{Resumo}

Nesta pesquisa, apresentamos algumas características teológicas e rituais próprias do Batuque, uma religião afro-brasileira típica do sul do Brasil, motivo pelo qual também é referido como Batuque afro-sul. Colocamos esta tradição em perspectiva, olhando-a no contraste com outras tradições religiosas afro-brasileiras, bem como introduzimos a sua característica teológica mais própria, chamada segredo de Orixá, dando seu conceito, sua finalidade ritual e as possíveis origens desta tradição peculiar ao Batuque.

Palavras-chave: Batuque. Orixá. Ritual. Pessoa.

\section{RITUALIDADES DEL MISTERIO PERSONAL: EL "SECRETO DE ORIXÁ" EN EL BATUQUE AFRO-SUR}

\section{Resumen}

En esta pesquisa presentamos algunas características teológicas y rituales propias de Batuque, una religión afrobrasileña, típica del sur de Brasil, por lo cual también es llamada como Batuque afro-sur. Esta tradición la ponemos en perspectiva, mirándola en contraste con otras tradiciones religiosas afrobrasileñas, bien como introducimos su característica teológica más propia, llamada secreto de Orixá. Presentamos su concepto, su finalidad ritual y posibles orígenes de esta tradición peculiar de Batuque.

Palabras-clave: Batuque. Orixá. Ritual. Persona.

\section{Introdução}

Nossa pesquisa pretende apresentar a tradição religiosa afro-brasileira chamada Batuque no contexto das demais tradições presentes no Brasil. Nosso fim último, todavia, não se restringe a um apanhado geral do estado dessa tradição no Brasil. Aqui nos limitaremos a análise de uma de suas dimensões litúrgicas e rituais mais desconcertantes, conhecida como segredo de Orixá. Apresentaremos o seu conceito, a sua importância dentro do ritual, bem como possíveis causas para sua origem.

Nosso método remonta à leitura de bibliografia especializada, também à experiência junto a casas de religião afro no Rio Grande do Sul e em Santa Catarina.

\footnotetext{
${ }^{1}$ Universidade Federal de Santa Catarina. Email: mvinicius.snunes@gmail.com
} 
Não se trata, contudo, de uma análise de dados etnográficos. Partimos dos dados desenvolvidos nas ciências sociais, que são indispensáveis em direção a uma reflexão que lê existencialmente o fenômeno afrorreligioso e que deságua no campo de uma possível teologia afrorreligiosa, ou ainda, afroteologia, buscando compreender seu sentido e seus contributos para uma reflexão mais ampla para as ciências da religião.

Em primeiro lugar, trataremos de apresentar um amplo escopo das religiões afrobrasileiras. De que modo podem ser agrupadas, quais são as características mínimas comuns que nos permitem classificá-las de tal ou qual modo e seus traços teológicos fundamentais, em especial a noção de possessão.

Em seguida apresentamos o Batuque. Suas principais nações, seus traços litúrgicos e teológicos peculiares. Em especial trataremos do segredo de Orixá, fato litúrgico e teológico que, segundo nossas pesquisas, é exclusivo dessa tradição afrorreligiosa. Aventaremos possíveis causas para tal peculiaridade, tanto de ordem material - econômica, social, política - quanto de ordem teológica intrínseca.

\section{As religiões afro-brasileiras}

O campo das religiões afro-brasileiras é complexo e diversificado. Mesmo o termo religiões afro-brasileiras é passível de questionamento. Haveria diferença entre estas e um conceito mais genérico, de religiões de matriz africana. O que faz uma religião ser afro-brasileira ou de matriz africana?

Alguns julgam possível fazer uma ampla distinção entre religiões de matriz africana aculturadas e não aculturadas. Esta classificação aparece em importantes textos da etnologia (SANTOS, 2012), e inclusive é a divisão adotada pelo IBGE na realização. Nós a adotamos em parte. Questionamos a possibilidade de falarmos em religiões não aculturadas. Circula fortemente entre os afro-religiosos o mito da pureza teológica e litúrgica. Alguns cultos teriam guardado, quase que intacta, a pureza das tradições africanas enquanto outros, no extremo oposto, teriam a tal ponto se afastado de tais tradições que mesmo o termo afro não lhes poderia ser facilmente aplicado.

Contudo, ceder a esta divisão tão clara seria, a nosso ver, ceder às reelaborações identitárias próprias, sem dúvida válidas, feitas em contexto cultual, que expressam uma legítima construção teológica própria de determinados grupos religiosos, mas que dentro de nossas perspectivas conceituais não corresponde plenamente aos fatos 
culturais que aqui apresentamos. Por isso apresentamos nesta introdução uma classificação das religiões afro ${ }^{2}$ em dois grandes grupos, um menos aculturado e outro mais aculturado, pois levamos em conta que no primeiro também há evidentes traços de aculturação e no outro também evidente busca de tradições e matrizes culturais tradicionais.

Dentro do grande grupo das religiões afro menos aculturadas situam-se o sem número de Candomblés, Batuques, Xangôs, que genericamente são chamados Nações. Três grandes grupos étnicos estão na origem dessas nações, o jeje, proveniente da região do atual Benin, o nagô ou yorubá, vindos da atual Nigéria e parte do Benin e o bantu, da costa ocidental sul da África, principalmente da Angola e Congo. A cada um desses grupos étnicos corresponde uma língua, ainda usada liturgicamente: O fon para os jejes, o yorubá para os nagôs e o kimbundo para os bantus. A conservação da língua litúrgica é uma das marcas dessas religiões menos aculturadas. Ademais, cultuam prioritariamente, se bem que nem sempre exclusivamente, as divindades dos panteões de seus lugares de origem: Vodun, para os jejes, Orixás, para os nagôs, Inkices para os bantus. Quando dizemos, por exemplo, candomblé, sob esta rubrica abrigam-se uma variedade gigantesca de tradições teológicas, litúrgicas, filosóficas, linguísticas. Por exemplo, mesmo um candomblé de origem nagô pode ser Candomblé Ketu, Candomblé Ijexá, pode ser ainda um culto de nação Nagô-Egbá, ou mesmo mesclada com o culto jeje, como Nagô-Efon.

No grande grupo das religiões mais aculturadas se encontram as umbandas, juremas, quimbandas, que mesclam muitos elementos da cultura popular, do cristianismo, da cultura indígena com elementos afros, especialmente nagôs e bantus. Sua língua litúrgica é o português e seu panteão inclui o culto de arquétipos da cultura popular, como o preto-velho, o indígena, o marinheiro, a criança. São ritualmente menos complexas, apesar de gozarem de patrimônio litúrgico e teológico próprio.

Entretanto, a separação entre esses dois grandes grupos não é tão rígida quanto à primeira vista pode nos parecer. Há muitos trânsitos simbólicos que ocorrem em diversas áreas, seja em divindades que se incorporam de um lado para outro, na língua, nas roupas, na compreensão teológica. Ao fim, talvez pudéssemos falar de um único grande grupo que varia em uma grande escala de aculturação.

\footnotetext{
${ }^{2}$ Seguindo a nossa classificação, uma possível disjunção entre religiões afro-brasileiras e religiões de matriz africana não se justifica. Assim, muitas vezes usamos apenas a expressão religiões afro para amplamente conter o maior número possível de nuances de sentido.
} 
O nosso trabalho se restringe a uma específica tradição dentro do grande grupo menos aculturado, a saber, do Batuque afro-sul. Dentro do grande escopo de pesquisas e estudos, desde tantas perspectivas teóricas, o grupo nagô tal como mantém suas tradições, especialmente na Bahia e no sudeste, se tornou o grande padrão normativo, o cânon da pesquisa e também do culto. Outras tradições, como o Batuque, acabam por serem menos consideradas. Aqui trataremos da tradição religiosa afro-sul a partir de determinados pontos de divergência em relação a outros grupos contemplados em tantas pesquisas feitas no Brasil e no exterior.

\subsection{Religião de possessão}

É, até certo ponto, lugar-comum dizer que as religiões afro-brasileiras são religiões de possessão. Mas o que significa isto de fato? O substantivo parece sugerirnos que algo, ou alguém, possui, toma posse de outro algo ou alguém. Assim entendido, a maioria das pessoas é levada a crer que um espírito toma posse do corpo dos seus "médiuns".

Até certo ponto esta opinião não está equivocada. Mas é preciso distinguir ao menos dois contextos teológicos diversos. No contexto umbandista o termo incorporação de fato se aplica com mais precisão. Influenciada por elementos da doutrina espírita, a Umbanda crê que nos seus rituais um espírito de alguém desencarnado volta. Esta volta tem dois motivos. O primeiro é ajudar as pessoas que buscam seu auxílio, com curas espirituais, aconselhamentos, energizações. O segundo motivo é que através desse trabalho espiritual o espírito desencarnado alcança méritos para sua evolução.

O fato é que as entidades que incorporam não são deuses como no Candomblé africano, mas espíritos organizados em legiões ou grupamentos colocados sob os auspícios dos Orixás. Na concepção cósmica, os Orixás correspondem aos reinos da natureza. Temos, então, legiões do mar (Iemanjá), do vento (Iansã), das matas (Oxóssi), etc. Além dessa correspondência cósmica, as entidades pertencem a grupos que encontram sua ressonância na sociedade e na formação do povo brasileiro: os índios (Caboclos), os negros (Preto-Velhos), as prostitutas (Pombagiras), os malandros (Exús), crianças, orientais, ciganos, marinheiros, boiadeiros, baianos, cangaceiros, juremeiros, turcos, etc. (DRAVET, 2016, p. 297) 
Deste modo, a complexa hierarquia espiritual da Umbanda reflete um quadro de evolução espiritual no plano cósmico, justificando que a pessoa desencarnada "volte como" uma pombagira, um preto-velho, um caboclo. Pode ainda voltar como um capangueiro de Orixá, um espírito que se apresenta com um nome de Orixá, como Ogun, ou Oxóssi, Yemanjá, porque seu trabalho se dá na vibração desse Orixá.

As coisas se dão de modo diferente nos grupos menos aculturados. Pelo menor ou nulo sincretismo com o espiritismo europeu, seus cultos não são, em sua grande maioria, culto de espíritos desencarnados ${ }^{3}$. Parte da teologia dos Orixás expressa a ideia de que os Orixás são antepassados não meramente desencarnados, mas divinizados. São chamados írunmale $\underline{e}^{4}$. Mas a teologia nagô, por exemplo, também fala dos òrìsà em sentido estrito, criados diretamente por Ólórun como dinamizadores do seu àse . (SANTOS, 2012).

Bastide (2001) ciente dessa diferença usa indistintamente os termos possessão e transe para o fenômeno que ocorre nos cultos de Orixá, mas não incorporação. No transe fica evidenciado o fenômeno litúrgico e social, uma espécie de "ópera mítica" (BASTIDE, 2001) que de forma alguma pode ser tratada como um fenômeno individual. O canto e a dança, o som dos atabaques e as orações não têm por finalidade apenas invocar a divindade, mas representam um ciclo cósmico, uma ìtan, isto é, uma história específica de uma divindade. Enquanto na Umbanda uma mesma pessoa pode incorporar várias entidades diferentes, às vezes durante o tempo de um mesmo culto, nas tradições menos aculturadas apenas o Orixá da pessoa se manifesta. Os religiosos de Candomblé, por tal, preferem a expressão virar ou bolar no Orixá.

Com esses termos fica indicado, mas não explicitado, uma outra dimensão do transe de Orixá. Trata-se da manifestação de uma dimensão da personalidade, ou ao menos como uma "metamorfose da personalidade" (BASTIDE, 2001). A seguir apresentaremos o Batuque e a sua compreensão de transe de Orixá. Parece-nos possível ver no transe a possibilidade de uma compreensão existencial de si como mistério, que tem na manifestação litúrgica do Orixá o seu ponto mais alto.

\footnotetext{
${ }^{3}$ Exceção deve ser feita ao culto de egun ou egungun, o culto dos antepassados da comunidade. Este, todavia, não é praticado em muitas casas, sendo realizado apenas por sacerdotes inteiramente consagrados a ele. No Batuque, especialmente em algumas de suas nações, o culto de antepassados é mais difundido, sendo o seu sacerdote o mesmo do culto dos Orixás. O que é mais importante ressaltar é que em nenhum momento se confundem culto de antepassados e de Orixás, como acontecem nas tradições mais aculturadas, como a Umbanda

${ }^{4}$ A língua dos cultos afro de origem nagô é o yorubá. Na medida do possível usamos os termos já aculturados, aportuguesados. Quando mantivemos o termo em yorubá, citamos em itálico e conforme a ortografia do yorubá moderno.
} 


\section{O Batuque afro-sul}

Aqui não apresentamos uma introdução pormenorizada da teologia do Batuque. Antes, nos restringimos a algumas características da manifestação litúrgica de Orixás na tradição de matriz africana chamada Batuque, típica do Rio Grande do Sul. A centralidade dos ritos de origem yorubá (entre o território da Nigéria e Benin) se encontra no culto ao Orixá, que na pluralidade de suas teologias é apresentado ora como antepassado divinizado, ora como força da natureza, ou mesmo como uma espécie de arquétipo da personalidade.

Ainda que não precisemos de justificativas estatísticas para deduzir a relevância das particularidades litúrgicas de alguma religião particular, como é o caso do Batuque afro-gaúcho (ou batuque afro-sul), vale a pena conhecermos alguns dados apresentados pelo IBGE (2000; 2010).

No censo de 2000, o Rio Grande do Sul aparece com 1,62\% da população que se declarava adepto de religião de matriz afro, contra $1,31 \%$ no Rio de Janeiro, que ocupava o segundo lugar nacional e contra apenas $0,08 \%$ da Bahia. O censo de 2010, apesar de referir um decréscimo percentual, ainda confirma essa liderança.

Estima-se a existência no estado de mais de 30.000 templos religiosos afro (tradicionalmente chamados "terreiras"), com grande concentração na região metropolitana de Porto Alegre. Com todos esses dados, hoje o Rio Grande do Sul sozinho concentra $23 \%$ do total de adeptos de religiões afro de todo o Brasil (ORO, 2012). Sem falarmos ainda na expansão do batuque para outras regiões do Cone Sul, como a Argentina e o Uruguai (ORO, 2009).

O nome Batuque (assim como o nome "umbanda" ou "candomblé") inclui grande número de tradições heterogêneas. As nações ou "lados" do Batuque são o nagô (de menor expressão e mais próximo às expressões dos candomblés das regiões nordeste e sudeste do país), o Oyó (Igbomina e Bangan), a Kambina (ou Cabinda), o Jeje e o Ijexá. É muito difícil definir, com precisão, as especificidades de cada nação, suas origens e desenvolvimento. Há uma mescla histórica e explícita dos "lados" onde se formam nações "híbridas” como a nação Jeje-Ijexá, caso mais tradicional de hibridez. Em menor medida, mas igualmente expressivas, se fala em nação Oyó-Ijexá, ou mesmo Jeje-Kambina. O elemento predominante em todas essas nações é o yorubá, seja na 
língua litúrgica, seja nas divindades cultuadas, seja na elaboração teológica e filosófica (SILVEIRA, 2014). A presença do elemento Jeje se verifica pelo culto a algumas divindades, ou que ao menos são mencionadas em algumas cantigas (Legba, Sogbô); por similaridades com o culto de Vodun que podem ser observadas (ABIOU, 2016); seja pela presença do príncipe Osuanlele Erupé, de origem jeje, no Rio Grande do Sul, que influenciou em boa medida a organização dos cultos de nação (SILVEIRA, 2014; SILVA, 1999). Entretanto, a extensão real da influência do Jeje é passível de discussão. Por exemplo, sua língua litúrgica, o Fon, não é utilizada no Batuque 5 .

Quanto à presença da religião bantu nos encontramos em terreno ainda mais difícil de averiguar. Uns pretendem ligar a nação Cabinda a uma origem bantu (SILVEIRA 2014). Reconhecem no patrono desta nação, Kamuká, associado ao culto de Xangô, um nome bantu, assim como seria bantu a importância que se dá ao culto dos antepassados, que nesta nação, ordinariamente, precede na ordem litúrgica o culto aos Orixás. Ainda poder-se-ia reconhecer no fundador mítico dessa nação no Rio Grande do Sul, certo africano chamado Gululu, um nome bantu. Entretanto, sua liturgia é yorubá, sua língua de culto é yorubá (inclusive as dedicadas ao seu patrono Kamuká), e mesmo seu nome seria mais corretamente lido Kambina em referência ao antepassado mítico de Xangô Okambi, e não Cabinda, nome de uma província da moderna Angola. Fora as já mencionadas e algumas outras poucas especificidades próprias suas, é no mais em tudo similar às outras nações do Batuque afro-sul.

\section{Segredo de Orixá}

Uma marca, entretanto, perpassa todas as nações do Batuque (com exceção, talvez, da chamada nagô, apesar de todas serem nagôs, que conforma um todo teológico-ritual bem diverso). Nelas o transe constitui um tabu, em geral chamado segredo de Orixá. Constitui, segundo nossa pesquisa, característica exclusiva de tais nações. Consiste na proibição expressa tanto ao cavalo-de-Santo (elegun) quanto aos membros de sua família religiosa, como a qualquer assistente dos rituais de falar qualquer coisa sobre a manifestação ocorrida.

\footnotetext{
${ }^{5}$ Talvez não tenham ido para o Rio Grande do Sul jejes "verdadeiramente" fon, mas habitantes do antigo Daomé de origem yorubá, que os jeje chamavam ànàgónu. Não passa, todavia, de uma hipótese de difícil comprovação.
} 
O transe recebe na tradição do Batuque o nome de ocupar-se do Orixá. Um cavalo-de-santo não vira no santo, não bola, não manifesta, muito menos incorpora, mas “se ocupa do seu Orixá". Este fato, contudo, jamais poderá ser-lhe dito diretamente. Isto feito, o culpado de "descobrir o segredo" de outrem recebe pesadas sanções rituais, como o pagamento de multas com animais e objetos litúrgicos para os sacrifícios necessários para "cobrir" de novo o segredo. Em praticamente todas as casas corre a tradição de quem "descobre que se ocupa" pode sofrer vários males espirituais, emocionais e físicos, inclusive a loucura.

A nossa pesquisa se interessa em pensar algumas indicações que possam lançar luz sobre essa peculiaridade do Batuque afro-sul. Quais seriam suas origens? A finalidade é meramente ritual? Mas, o que seria nesse caso meramente ritual? Haveria aí uma história de proteção de vínculos sociais através da proteção dos vínculos litúrgicos? Em nossa presença junto a muitas casas de Batuque percebemos que, em algumas delas, mais em umas nações e menos em outras, esse tabu é um pouco mais relaxado. Em algumas, por evidente influência de outras tradições afros, como o Candomblé. Outras, pelo regime litúrgico próprio da mesma nação, menos rígido em tal questão. Em outros casos, percebemos uma rígida observância de tal preceito.

\subsection{Origens do segredo}

A origem dessa tradição é muito difícil de avaliar. Certo que no Rio Grande do Sul, apesar da presença de uma corte africana (a de Osuanlele Okizi Erupé) e as boas relações políticas que esta mantinha com o poder político local, não se pode dizer que o Batuque tenha encontrado um ambiente favorável ao seu desenvolvimento. As condições econômicas eram bem diversas daquelas encontradas no nordeste brasileiro de então (final do século XIX e início do XX). Os rituais se tornaram muito mais econômicos, barateados. Pouco a pouco os tempos de iniciação foram se reduzindo. Rituais mais dispendiosos foram sendo abandonados. A terreira, como é chamado tradicionalmente no Batuque o conjunto dos espaços sagrados dedicado ao culto dos Orixás, equivalia à casa do babaláo e da babalôa ${ }^{6}$. O quarto-de-santo, onde ficam os

\footnotetext{
${ }^{6}$ Tradicionalmente o pai e a mãe de santo eram chamados na tradição batuqueira, respectivamente, de babaláo e babalôa, provavelmente corruptelas de bàbálawo, pai-do-segredo, sacerdote iniciado no culto de Ifá, divindade da advinhação. Do início da década de 1990, pelo contato com outras tradições de matriz africana e pelo despertar da pesquisa sobre as origens, começou a aparecer o uso dos termos babalorixá e yalorixá, com o quase total desaparecimento dos usos anteriores. Também a expressão
} 
objetos litúrgicos dos orixás, muitas vezes não passava de uma prateleira coberta com cortinas na sala da casa do babaláo, sala que funcionava como salão para as danças dos orixás. Os assentamentos externos, altares (os peji, ajubo e ojubo) dão lugar a mínimas credências, armários ou casinhas no exterior da casa onde se abrigam os assentamentos de Bará Lodê, Bará Lanã, Ogun Avagan, Oyá Dirã e Oyá Timboá, assim como outros Orixás menos cultuados, próprios de apenas uma ou outra entre as várias tradições, como Legba, Zina, Gama.

Às condições econômicas muito limitadas se deve somar a pouca aceitabilidade social do batuque. Apesar do dado de $23 \%$ da população brasileira adepta de religiões de matriz africana, mais ou menos aculturadas, se encontrar no Rio Grande do Sul, isto garantiu pouca visibilidade identitária de grande expressão até finais do século XX, onde se reconhece uma organização mais consistente em busca de direitos. A nossa grande pergunta é se é possível vincular o segredo de Orixá à repressão exercida sobre as casas de Batuque. Não haveria aí uma saída litúrgica para uma sanção sociológica que seria miticamente mediada? Poderia haver maior sanção que a loucura, isto é, a exclusão total da comunidade de fala? A necessidade de proteção da comunidade poderia ter gerado essa artimanha.

Contudo, parece-nos difícil explicar tal acontecimento apenas pela via sociológica extrínseca. É preciso buscar as raízes dos próprios ritos dentro da própria religião yorubá. Parece indiscutível que os rituais do Batuque têm parte de suas raízes no culto de Xangô realizado na cidade de Oyó. Primeiro, reconhecemos uma nação do Batuque homônima da cidade onde o Orixá Xangô é rei e onde é cultuado. Segundo, percebe-se o papel de patrono principal de Xangô nas nações Oyó (Igbomina e Bangan) e na Kambina, onde é cultuado como Xangô Kamuká. E o mais importante, o papel que o culto de Xangô tem em todo o batuque.

A principal dança do Batuque só é executada nas festas grandes, ou batuques de quatro-pés. Para serem realizadas, tais festas são antecedidas pelo sacrifício de vários animais, em especial quadrúpedes, como cabritos, porcos, ovelhas, donde seu nome. É também nessas festas que os babalorixás e yalorixás são feitos, isto é, consagrados como babalorixás. Para confirmar que os Orixás receberam os sacrifícios se realiza essa dança dedicada a Xangô chamada balança de Xangô, ou kasun. Nesta participam apenas os

terreira tem cedido espaço para ile, ile àse, terreiro. Mas ao contrário do caso anterior, a expressão terreira parece fazer parte mais constante do vocabulário diário das casas de religião, como também são chamadas. 
prontos, isto é, que já deram obrigações maiores aos seus Orixás, que já são babalorixás e yalorixás. Dão-se as mãos, voltados para o centro da roda que se encontra vazio, numa dança que começa em marcha bem lenta e vai acelerando. É nesta dança que se manifestam os Orixás ditos secos, a saber: Bará, Ogun, Oyá, Xangô, Odé, Obá, Ossanha e Xapanã.

A balança não pode ser rompida, isto é, os que dela participam não podem de maneira alguma soltar suas mãos antes do momento ritual prescrito, quando ocorre uma mudança no toque da dança. As penas para o rompimento são as mesmas para a revelação do segredo de Orixá. Desfeita a balança, os Orixás manifestados dançam alegremente, em frente aos tambores, os Alujás de Xangô e Oyá e o jeje de Xangô. É um ritual de máxima importância, realizado com máxima solenidade, que não pode ser de forma alguma fotografado ou filmado. É a mais sagrada das danças no Batuque, apesar de serem conhecidas outras balanças, como a de Xapanã ou a de Obá, menos solenes e menos rígidas em suas sanções. Ou danças como a do Alá, realizada para Oxalá, que são tratadas com uma reverência especial.

Segundo Verger (1997), nos rituais para Xangô realizados em Oyó, na Nigéria, a manifestação do Orixá acontece com violentas convulsões. Após isso, o corpo do elegun relaxa e Xangô mantém-se durante o ritual, manifestado no elegun, de forma serena e cerimonial. Entretanto, o fim da manifestação não é tão brusco quanto o seu início. O elegun passa do estágio de manifestação do Orixá a um segundo estágio onde " $O \underline{s} e$ bi asiwère" (literalmente, age como um louco) com comportamento infantil, tresloucado. Após ainda esse estágio, passa para um outro de sonolência e fraqueza onde não se lembra do que aconteceu. Ora, nesta palavra asiwère reconhecemos uma possível origem do termo axero, muito usado no Batuque. Nas nações do Batuque, o Orixá, ordinariamente, não abandona seu cavalo-de-santo repentinamente. Quando termina a manifestação, o filho-de-santo permanece num estágio chamado intermediário entre o Orixá e a consciência plena, que é o axero. Comporta-se também infantilmente, usa uma gramática própria e incompreensível para quem não conhece o ritual. Quando o filho sai do estado de axero não se recorda de nada do que lhe aconteceu. Parece possível reconhecer aí elementos do culto realizado em Oyó tal como de descrito por Verger, embora não possamos fechar a questão. 


\subsection{A rigidez da norma}

Já que a manifestação do Orixá no Batuque é envolta em todo esse segredo, pode-se imaginar o que representa a primeira vez em que se manifesta em seu filho, ou como se diz em linguagem batuqueira, quando nasce o Orixá. Não se pode provocar a manifestação de forma que o iniciado a perceba. Tampouco o filho de santo no Batuque dá sinais de sentir vibrações, energias (ou mesmo "dar ekê", expressão que funciona às vezes pejorativamente) como é comum em outras tradições afro, como no Candomblé. A primeira manifestação em geral é repentina e violenta, dentro de rituais de iniciação não públicos, ou em momentos públicos importantes, como em uma festa grande, durante alguma dança. As manifestações seguintes também seguem o mesmo padrão: sem apresentar sinais visíveis o Orixá manifesta-se abruptamente, às vezes de maneira mais violenta, com movimentos bruscos do corpo, em silêncio (sem gritar ou falar, o que só lhe será permitido em ritual posterior), ou mesmo alguns gritando. Isto depende do Orixá, da casa, da nação.

O que pudemos perceber é que em algumas casas o segredo de Orixá não é tratado tão rigidamente. Segundo nosso parecer podemos atribuir essa variação a três causas distintas. Algumas nações observam mais estritamente o segredo, outras menos, como característica litúrgica própria. Pudemos perceber, em geral, uma observância mais rigorosa em casas de Jeje-Ijexá, casas de Kambina que vão da rigidez a uma conduta bem frouxa, e casas de Oyó que parecem nem o observar. A independência das nações entre si e das casas dentro de uma mesma nação deriva nessa relativa liberdade frente à tradição que impede a existência de normas gerais e absolutas para todos.

A segunda causa cremos poder atribuir ao fato de haver algumas yalorixás e alguns babalorixás que fizeram a passagem por outros rituais antes do Batuque, como o Candomblé. Para esses, a questão do segredo lhes parece de menor importância ou, ao menos, encarada de forma menos rígida, sem preocupações com as sanções ou com a possível loucura impingida pelos Orixás a quem tem seu segredo descoberto.

Em terceiro lugar, não podemos deixar de ressaltar o fato que muitos babalorixás e yalorixás têm se aprofundado em estudos, têm se aproximado de outras tradições, têm feito verdadeiras experiências teológicas e litúrgicas, mais difíceis em outras épocas, que lhes têm levado a relativizar tal aspecto de suas próprias tradições. São novas 
formas de apropriação da própria tradição e novas maneiras de transmissão que levam a reflexão sobre as origens históricas de sua ritualidade e teologia.

Não obstante todas essas transformações, a maior parte dos batuqueiros considera o segredo de Orixá parte essencial do ritual e por conseguinte não negligenciável ou passível de ser relativizada. Algumas narrativas são elaboradas sobre essa essencialidade: uma maneira de preservar os sacerdotes do orgulho e da soberba por terem um contato tão íntimo com o Orixá, uma maneira de manter uma respeitosa diferença e distância em relação à divindade, o que ajudaria a impedir o uso do transe para a promoção própria.

Talvez devêssemos simplesmente tomar o segredo de Orixá como um dogma do Batuque. A expressão pode não parecer boa, mas é capaz de explicar antropologicamente esse aspecto de sua tradição. De fato, do ponto de vista da história da religião, é comum encontrarmos proibições que não se justificam prima facie, isto é, que não são tão evidentes como outras sanções, por exemplo, como as de tipo moral que proíbem matar um membro do grupo sem justa causa, ou que imponha o cuidado dos membros mais frágeis da comunidade. Os ritos religiosos de um grupo, com suas proibições e recomendações, suas normas mais ou menos estritas, apresenta performativamente as relações que se entravam a partir de uma visão de mundo, de uma compreensão do todo, da própria realidade, da própria história.

O segredo de Orixá pode propor-nos uma maneira de ver a vida humana que ainda não tenhamos acolhido: de respeitar o mistério da pessoa em sua essência divina. O divino no humano é intocável, inalienável, e o inalienável no humano, o que constitui a dignidade humana é algo em si divino. Mas isso já é extrapolar os limites desta pesquisa.

\section{Conclusão}

O nosso trabalho apresentou a similaridade do Batuque com as outras religiões afro-brasileiras do campo menos aculturado. Guarda com essas muitas semelhanças teológicas rituais. Todavia, a sua peculiaridade constituinte, o segredo do Orixá, nos coloca muitas questões.

Aventamos muitas possíveis causas. Mas não há como assegurar-nos que um ou outro fator determinante tenha originado essa tradição exclusiva do Batuque. Duas teses 
conjugadas podem apresentar uma resposta interessante. Parece provável que as causas sociológicas acima apresentadas, as condições econômicas, a perseguição policial, tenham contribuído para que se realizasse um culto mais econômico, não apenas quanto ao espaço sagrado reduzido ou ao uso de certos materiais. O culto do Orixá se tornou ritual e teologicamente mais econômico. A possível reminiscência simbólica do culto realizado em Oyó, que envolvia um estado de consciência alterado mais longo, provocando esquecimentos e letargias depois do transe, pode ter sido recuperada ainda que inconscientemente nessa prática litúrgica.

Ir além da descrição do fato e perguntar-se por suas origens pode ser, relativo à matéria por nós tratada, um pesado fardo sem resultados práticos. Entretanto, no horizonte simbólico das religiões afro-brasileiras, o segredo de Orixá do Batuque abre uma possibilidade inaudita. Encara-se a relação com a divindade como um mistério em que a própria integridade da personalidade é posta em jogo.

O transe é um acontecimento de tal maneira precioso a ponto da lembrança da fusão extática com o eu divino ser objeto de um cuidado extremo. Ninguém se pode valer da manifestação do Orixá. Nem o próprio elegun. Se por um lado o Orixá se apresenta como uma dimensão do eu da qual o elegun se ocupa, também é uma dimensão transcendente que não pode ser aprisionada por nada, por nenhuma discursividade, não pode ser dita.

\section{Referências}

ABIOU, Sèna Annick Laetitia. Religião Além da Vida: estudo comparativo de práticas religiosas entre os Vodunsi do litoral sudeste do Benin, na África subsaariana, e o Batuque do Rio Grande do Sul, no Brasil. Tese (Doutorado em Antropologia) - Instituto de Filosofia e Ciências Humanas, Universidade Federal do Rio Grande do Sul. Porto Alegre, p. 202, 2016.

BASTIDE, Roger. Candomblé da Bahia: rito nagô. São Paulo: Companhia das Letras, 2001.

CORRÊA, Norton Figueiredo. O Batuque do Rio Grande do Sul: antropologia de uma religião afro-rio-grandense. Porto Alegre: Cultura \& Arte, 2006.

DEMOGRÁFICO, IBGE Censo. Disponível em: http://www. ibge. gov. br. Acesso em 12.06.2018, v. 3, 2010. 
DRAVET, Florence. "O imaginário ou a comunicação entre corpo e linguagem. Problematização do fenômeno da incorporação no Brasil". In: Conexão - Comunicação e Cultura. Caxias do Sul. Vol. 15, n. 30 (jul/dez 2016), p. 287-306, 2016.

ORO, Ari Pedro. "O atual campo afro-religioso gaúcho". Civitas: revista de ciências sociais. Porto Alegre, RS. Vol. 12, n. 3 (set./dez. 2012), p. 556-565, 2012.

ORO, Ari Pedro. "Transnacionalização religiosa no Cone-Sul: uma comparação entre pentecostais e afro-religiosos". Debates do NER. Porto Alegre. Vol. 10, n. 16 (jul./dez. 2009), p. 225-245, 2009.

SANTOS, Juana Elbein dos. Os Nagô e a Morte. Petrópolis: Editora Vozes, 2012.

SILVA, Maria Helena Nunes da. O Príncipe Custódio e a Religião Afro-Gaúcha. Dissertação (Mestrado em Antropologia) - Centro de Filosofia e Ciências Humanas, Universidade Federal do Pernambuco, p. 226, 1999.

SILVEIRA, Hendrix Alessandro Anzorena et al. Não Somos Filhos Sem Pais: história e teologia do batuque do Rio Grande do Sul. Dissertação (Mestrado em Teologia) Programa de Pós-Graduação em Teologia, Escola Superior de Teologia. São Leopoldo, p.136, 2014.

VERGER, Pierre. Orixás: deuses iorubás na África e Novo Mundo. Salvador: Corrupio, 1997.

Recebido em: 07/06/2020

Aceito em: 07/10/2020 